\title{
Recent advances in testicular germ cell tumours
}

\author{
Teresa Mele ${ }^{1,2} \quad$ Alison Reid ${ }^{1^{*}} \quad$ Robert Huddart ${ }^{1,2}$ \\ ${ }^{1}$ The Royal Marsden NHS Foundation Trust, Sutton, UK \\ ${ }^{2}$ The Institute of Cancer Research, London, UK
}

\begin{abstract}
Testicular germ cell tumours (TGCTs) are the most common solid tumours in young men and have an excellent overall cure rate and prognosis. In most patients, localised disease is cured by surgery alone, and a minority of patients receive short-course adjuvant chemotherapy to reduce the risk of further relapse. Also, in about $80 \%$ of patients, metastatic disease can be cured by systemic cisplatin-based chemotherapy. Unfortunately, for a proportion of patients, the disease exhibits platinum resistance and relapse occurs. Despite further lines of systemic treatment, cure can be difficult to achieve in these patients and ultimately about $20 \%$ of them will die from disease progression. Addressing the mechanisms underpinning platinum resistance is critical to improving the survival and chances of cure for these patients. This review describes the latest advances in TGCT research focusing on the identification of novel biomarkers, genetic characteristics and exploring novel treatments.
\end{abstract}

\section{Keywords}

testicular germ cell tumours, germ cell cancer, genetic hallmarks, biomarkers, novel treatments

\section{Peer Review}

The peer reviewers who approve this article are:

1. Ben Tran, Medical Oncology, Peter MacCallum Cancer Centre, Melbourne, Victoria, Australia Competing interests: No competing interests were disclosed.

2. Constantine Alifrangis, Department of Medical Oncology, University College London Hospitals \& St Bartholomew's Hospital, London, UK

Competing interests: No competing interests were disclosed. 
*Corresponding author: Alison Reid (alison.reid@rmh.nhs.uk)

Competing interests: The authors declare that they have no competing interests.

Grant information : This review represents independent research funded by the National Institute for Health Research (NIHR) Biomedical Research Centre at the Royal Marsden NHS Foundation Trust and the Institute of Cancer Research, London. The views expressed are those of the authors and not necessarily those of the NIHR or the Department of Health and Social Care.

The funders had no role in study design, data collection and analysis, decision to publish, or preparation of the manuscript.

Copyright: (C) 2021 Reid A et al. This is an open access article distributed under the terms of the Creative Commons Attribution License, which permits unrestricted use, distribution, and reproduction in any medium, provided the original work is properly cited.

How to cite this article: Mele T, Reid A and Huddart R. Recent advances in testicular germ cell tumours. Faculty Reviews 2021 10:(67) http:// doi.org/10.12703/r/10-67

Published: 31 Aug 2021, Faculty Reviews 10:(67) https://doi.org/10.12703/r/10-67 


\section{Introduction}

Testicular germ cell tumours (TGCTs) are the most common cancer in young adult men ${ }^{1,2}$. These tumours represent a rare neoplasm on a population scale (about $1 \%$ of all oncological diagnoses in men) and their incidence has been increasing progressively over the last three decades ${ }^{3,4}$.

TGCTs arise mostly in the testis but can develop in extragonadal sites, albeit rarely (2-5\%). Histologically, they are classified as seminoma, non-seminoma (yolk sac, embryonal carcinoma, choriocarcinoma and teratoma) or mixed ${ }^{5}$.

In the last 40 years, excellent rates of cure and overall survival (OS) have been achieved, including in the metastatic setting, thanks to multimodality treatment but principally owing to the introduction of cisplatin-based chemotherapy regimens ${ }^{6}$. Unfortunately, in up to $30 \%$ of metastatic TGCT patients, their disease is not cured by initial systemic therapy and salvage treatment is required ${ }^{7}$. Limited therapeutic options are available for patients with platinum-refractory disease, and prognosis is dismal and cure rates are low $(<5 \%)^{8}$.

Staging and prognosis assessment are crucial in the disease management of TGCTs. Since its publication in 1997, the International Germ Cell Cancer Collaborative Group (IGCCCG) prognostic classification has provided a valuable tool for patients with TGCTs in defining risk stratification on the basis of histology, marker levels and metastatic sites (Table 1$)^{9}$.

Notably, the IGCCCG classification in advanced nonseminoma was recently redefined, and encouraging results have arisen from patients who received treatment in more recent years (1990-2013) compared with historical data based on treatments delivered prior to the 1990s. In the updated series, progression-free survival (PFS) improved for poor-risk patients (5-year PFS of $54 \%$ versus $41 \%$ ) whereas OS improved in all IGCCCG risk groups (5-year OS of 96\%, 89\% and 67\% respectively in good, intermediate and poor prognosis). A new prognostic model that includes older age and presence of lung metastases as additional negative factors has been proposed ${ }^{10}$. Also, a lactate dehydrogenase (LDH) cut-off of 2.5 times the upper limit of normal has been proposed to refine the classification of seminoma patients without non-pulmonary visceral metastases (formerly included in the good-prognosis group) as their outcome reflects the IGCCCG intermediate-risk group ${ }^{11}$.

The PFS and OS improvements highlight progress in the management of TGCTs over the last 30 years but also confirm the need for further research focused on patients with cisplatin-refractory disease or relapse and those with late relapses (occurring 2 or more years after the completion of treatment).

This review discusses recent developments in testicular cancer biology and clinical management, focusing on the following areas:

- $\quad$ tumour markers and biomarkers

- $\quad$ genetic predisposition and hallmarks

- $\quad$ platinum-resistant disease and novel treatments.

\section{Tumour markers and biomarkers}

Tumour serum protein markers ( $\alpha$-fetoprotein, human chorionic gonadotrophin and $\mathrm{LDH}$ ) are widely used at diagnosis, in monitoring treatment response and in follow-up ${ }^{12}$. Additionally, their levels contribute to the risk stratification of patients with metastatic non-seminoma according to the IGCCCG prognostic classification'. However, in a significant proportion of patients, disease will be marker-negative and therefore tumour marker levels will not reflect disease burden ${ }^{13}$.

There is an unmet need for biomarker development in the following areas of clinical practice:

- $\quad$ improving diagnostic performance at disease outset

- using biomarkers to aid in identifying which stage 1 patients will relapse and should be offered adjuvant chemotherapy, sparing those who do not require it

- $\quad$ improving early detection of relapse, particularly in those patients who are non-secretors of the traditional TGCT markers; this may allow a reduction in the

Table 1. International Germ Cell Collaborative Group Prognostic Classification (1997).

\begin{tabular}{|c|c|c|c|}
\hline & Good & Intermediate & Poor \\
\hline Seminoma & $\begin{array}{l}\text { Any primary site } \\
\text { No NPVM }\end{array}$ & $\begin{array}{l}\text { Any primary site } \\
\text { NPVM }\end{array}$ & Not applicable \\
\hline Non- seminoma & $\begin{array}{l}\text { All criteria: } \\
\text { Gonadal/RP primary } \\
\text { No NPVM } \\
\text { hCG }<5000 \mathrm{IU} / \mathrm{L} \\
\text { AFP }<1000 \mathrm{ng} / \mathrm{mL} \\
\mathrm{LDH}<1.5 \mathrm{ULN}\end{array}$ & $\begin{array}{l}\text { All criteria: } \\
\text { Gonadal/RP primary } \\
\text { No NPVM } \\
5000 \leq \mathrm{hCG} \leq 50,000 \mathrm{IU} / \mathrm{L} \\
1000 \leq \mathrm{AFP} \leq 10,000 \mathrm{ng} / \mathrm{mL} \\
1.5 \leq \mathrm{LDH} \leq 10 \mathrm{ULN}\end{array}$ & $\begin{array}{l}\text { Any criteria: } \\
\text { Mediastinal primary } \\
\text { NPVM } \\
\text { hCG }>50,000 \mathrm{IU} / \mathrm{L} \\
\text { AFP }>10,000 \mathrm{ng} / \mathrm{mL} \\
\mathrm{LDH}>10 \mathrm{ULN}\end{array}$ \\
\hline
\end{tabular}

AFP, $\alpha$-fetoprotein; hCG, human chorionic gonadotropin; LDH, lactate dehydrogenase; NPVM, non-pulmonary visceral metastasis; RP, retroperitoneal; ULN, upper limit of normal. 
radiation burden on these young patients and reduce imaging costs

- identifying patients with residual active disease in post-chemotherapy masses.

Recent data suggest a promising role for circulating microRNAs (miRNAs) in addressing such questions. miRNAs are non-protein coding RNAs that regulate the expression of protein-coding genes.

There is evidence of significant overexpression in the tissue of specific miRNA clusters (miR-371-373 and miR-302) in all TGCTs, regardless of histological subtype, patient age or site of primary presentation, but not in normal tissue ${ }^{14}$. The identification of stable serum miRNAs has led to a number of studies aimed at identifying miRNAs at time of diagnosis and in response to treatment ${ }^{15,16}$.

A prospective multicentre study of 616 patients with primary diagnosed TGCTs and 258 controls has shown extremely high sensitivity (90.1\%) and specificity (94\%) of miRNA-371a-3p (M371 test by quantitative polymerase chain reaction) in all TGCT subgroups except teratoma ${ }^{17}$. The promising role of microRNA 371a-3p has also been investigated in a cohort of 24 low-stage chemotherapy-naïve patients undergoing retroperitoneal lymph node dissection, and results have been excellent (area under the curve [AUC] on receiver operating characteristic [ROC] analysis 0.965 , sensitivity $100 \%$ and specificity $92 \%$ ). However, miRNA was not predictive of pure teratoma ${ }^{18}$.

miRNA levels have also been investigated as predictors of residual viable disease at retroperitoneal lymph node dissection after chemotherapy in 82 patients with TGCTs, and results were positive (AUC 0.874$)^{19}$.

Interestingly, in a recent pilot trial in 111 patients with TGCTs where miR-371a-3p expression was retrospectively and blindly analysed on prospectively obtained samples and compared against clinical events, extremely high sensitivity (96\%) and specificity (100\%) were demonstrated, along with a positive predictive value of $100 \%$ and a negative predictive value of $98 \%$ in predicting active TGCTs ${ }^{20}$

A recent comprehensive review addresses differences among studies conducted to date and miRNA performance ${ }^{21}$. Circulating miRNAs are being validated in prospective randomised clinical trials (Table 2).

Although further follow-up, validation and standardisation are needed, the excellent performance of miRNAs in terms of sensitivity, specificity and short half-life in these studies shows promise for positively impacting on patient management.

\section{Genetic predisposition and hallmarks}

Compared with other solid tumours, TGCTs have a strong inherited genetic basis which accounts for almost half of the disease risk $^{22}$. As far as development is concerned, TGCTs derive from reprogramming of cells in the early embryo and the germline, which dysregulates their developmental potency. A recent model identified seven types of TGCT, each harbouring unique epigenetic features ${ }^{23}$.

Genome-wide association studies have shed significant light on the factors leading to TGCT heritability, which, however,

Table 2. MicroRNA (miRNA) evaluation in current prospective clinical trials.

\begin{tabular}{|c|c|c|c|c|c|c|c|}
\hline Study & $\begin{array}{l}\text { Type of } \\
\text { study }\end{array}$ & Intervention & Line & Patients & Serum miRNA & Timing & $\begin{array}{l}\text { ClinicalTrials. } \\
\text { gov Identifier }\end{array}$ \\
\hline \multirow[t]{2}{*}{ AGCT1531 } & \multirow[t]{2}{*}{ Phase III } & $\begin{array}{l}\text { Active } \\
\text { Surveillance }\end{array}$ & NA & $\begin{array}{l}\text { Low-risk } \\
\text { Stage I }\end{array}$ & $\begin{array}{l}\text { - Correlation of } \\
\text { miRNA levels } \\
\text { and stage I } \\
\text { relapse }\end{array}$ & $\begin{array}{l}\text { - Pre orchidectomy } \\
\text { - Every } 1 \text { month } \times 3 \\
\text { - Every } 3 \text { months for } 1 \text { year } \\
\text { - Every } 6 \text { months for } 1 \text { year }\end{array}$ & \multirow[t]{2}{*}{ NCT03067181 } \\
\hline & & $\begin{array}{l}\text { Carboplatin } \\
\text { versus cisplatin } \\
\text { (+ etoposide, } \\
\text { bleomycin) }\end{array}$ & I & $\begin{array}{l}\text { Standard-risk } \\
\text { Metastatic }\end{array}$ & $\begin{array}{l}\text { - Marker decline } \\
\text { on treatment } \\
\text { - Identification } \\
\text { prognostic } \\
\text { miRNAs }\end{array}$ & Not available & \\
\hline UKP3BEP & $\begin{array}{l}\text { Phase III } \\
\text { randomised }\end{array}$ & $\begin{array}{l}\text { Accelerated } \\
\text { versus standard } \\
\text { BEP (bleomycin, } \\
\text { etoposide and } \\
\text { platinum) } \\
\text { chemotherapy }\end{array}$ & I & $\begin{array}{l}\text { Intermediate/ } \\
\text { poor-risk } \\
\text { Metastatic/ } \\
\text { Mediastinal } \\
\text { primary }\end{array}$ & $\begin{array}{l}\text { - Marker decline } \\
\text { on treatment } \\
\text { - Identification } \\
\text { prognostic } \\
\text { miRNAs }\end{array}$ & $\begin{array}{l}\text { - Day } 1 \\
\text { - Day } 22 \\
\text { - } \text { Day } 43 \\
\text { - End of treatment } \\
\text { - } 1 \text { year }\end{array}$ & NCT02582697 \\
\hline $\begin{array}{l}\text { SWOG } \\
\text { S1823 }\end{array}$ & $\begin{array}{l}\text { Prospective } \\
\text { cohort study }\end{array}$ & Surveillance & NA & Stage I & $\begin{array}{l}\text { - Correlation of } \\
\text { miR-371a-3p } \\
\text { levels and } \\
\text { stage I relapse }\end{array}$ & $\begin{array}{l}\text { - Pre-orchidectomy } \\
\text { - Post-orchidectomy } \\
\text { - } 3 \text { monthly (for } 2 \text { years) }\end{array}$ & NCT04435756 \\
\hline
\end{tabular}


is not yet fully elucidated. First, heritability is not related to a single high-penetrance risk locus but instead is highly polygenic, and up to 49 risk loci have been identified so $\operatorname{far}^{24,25}$. Second, the role of several signalling pathways, such as KIT-KITLG signalling and DAZL and PRDMI4 (both of which are involved in germ cell differentiation), has been identified as crucial to disease development and genomic integrity ${ }^{26}$.

Overall, TGCTs are characterised by a number of genetic hallmarks, which can be related to tumour development and can have an impact on treatment response and resistance.

Chromosomal abnormalities, such as increased copy number of chromosome p12 (mostly as isochromosome p12), which is a well-established pathognomonic factor in TGCTs, are common $^{27,28}$.

Also, unlike the majority of solid tumours, TGCTs, owing to their embryonic origin, are known to harbour a very low mutational burden and typically exhibit a lack of recurrent somatic non-synonymous mutations (mean of 0.5 mutations per megabase) $)^{29}$.

The Cancer Genome Atlas Research Network analysis on 137 primary GCTs showed somatic mutations in KIT $(18 \%)$, $K R A S(14 \%)$, and NRAS (4\%), exclusively in seminomas ${ }^{30}$.

Other identified mutations by whole-exome sequencing in 42 TGCT cases include the tumour suppressor gene CDC27 $(11.9 \%)$. Copy number analysis showed amplification of the spermatocyte development gene FSIP2 (15.3\%). In two patients with cisplatin-resistant disease, a missense XRCC2 mutation was also identified ${ }^{29}$.

\section{Platinum-resistant disease and novel treatments}

Platinum-resistant disease remains a management challenge in TGCTs, and there is no consensus on the optimum salvage treatment to achieve disease remission. Several platinum-based standard-dose chemotherapy regimens-VeIP (vinblastine + ifosfamide + cisplatin), VIP (etoposide + ifosfamide + cisplatin), TIP (paclitaxel + ifosfamide + cisplatin) and EP (etoposide + cisplatin) - are currently used in this setting ${ }^{31-33}$, as is high-dose chemotherapy followed by autologous bone marrow transplant ${ }^{34-38}$. The complexity and frequency of this situation mean that guidelines recommend that such treatment should be undertaken in specialist centres. Key to progress in this area is multicentre and multinational collaboration. This collaboration has been facilitated by the development of international germ cell tumour groups such as the International Global Germ Cell Tumor Collaborative Group (G3) and the Malignant Germ Cell International Consortium (MaGiC).

A key example of this is the international randomised phase 3 study (TIGER, ClinicalTrials.gov Identifier: NCT02375204) that is currently comparing conventional dose salvage treatment (TIP) with high-dose chemotherapy (two cycles of paclitaxel and ifosfamide followed by three cycles of carboplatin and etoposide). The study is actively recruiting and the results are long-awaited to inform the salvage treatment of TGCTs.

At a molecular level, platinum sensitivity and resistance have not been fully elucidated. It has been shown that platinum sensitivity depends highly on cisplatin-induced DNA damage (due to insufficient or inefficient nucleotide excision repair and double-strand break repair), intact p53 signalling ${ }^{39,40}$ and an increased chemotherapy-induced apoptotic response due to mitochondrial priming ${ }^{40}$.

p53 mutations and MDM2 amplifications have been identified in platinum-resistant TGCTs, particularly in those with adverse clinical features, and have been related to poor outcomes independent of the IGCCCG risk class ${ }^{41}$.

Recent whole-exome sequencing on platinum-resistant TGCTs, compared with platinum-sensitive tumours, has shown several hallmarks of platinum-resistant disease, including increasing copy number and structural aberrations and an increased frequency of mutations affecting KIT, p53 and WNT/CTNNB1 signalling genes as well as loss of pluripotency genes and hypermethylation $^{42}$. For example, in a 2016 study $^{40}$, apoptosis and pluripotency regulators NANOG and POU5F1 (also known as OCT3/4) expressed in TGCTs were not expressed in metastatic tumour deposits or mediastinal GCTs resistant to chemotherapy. However, the exact impact of these changes and the impact on mitochondrial priming are unknown.

Further research is needed to address the molecular basis of cisplatin resistance, and the exploration of novel treatments is a priority to improve outcomes in resistant disease.

A comprehensive description of targeted and novel treatments explored in TGCTs is beyond the scope of this review and has been addressed by others ${ }^{39,43}$. As summarised in Table 3, pathways explored include VEGF/PDGF-mediated angiogenesis, receptor tyrosine kinases (for example, c-KIT and MET), mechanistic target of rapamycin (mTOR) signalling, cyclindependent kinases, and poly (ADP-ribose) polymerase (PARP)mediated DNA repair. Early-phase trials exploring the role of these novel agents in refractory TGCTs have shown disappointing results overall. While acknowledging that these studies often include heavily pre-treated patients, some of these studies were terminated early because of futility and because the observed overall response rates and outcomes were extremely poor. At the same time, it should be recognised that most of these studies have been in unselected patients.

A phase II single-arm study of pazopanib, an angiogenesistargeted treatment, in 43 patients who had progressed after two or more platinum-based regimens yielded a 3-month PFS of $12.8 \%$ and a 1 -year OS of $28.5 \%{ }^{44}$. Likewise, despite promising pre-clinical activity, sunitinib showed poor clinical results in patients with cisplatin-refractory disease (partial responses ranged from 0 to $9 \%)^{45,46}$. 


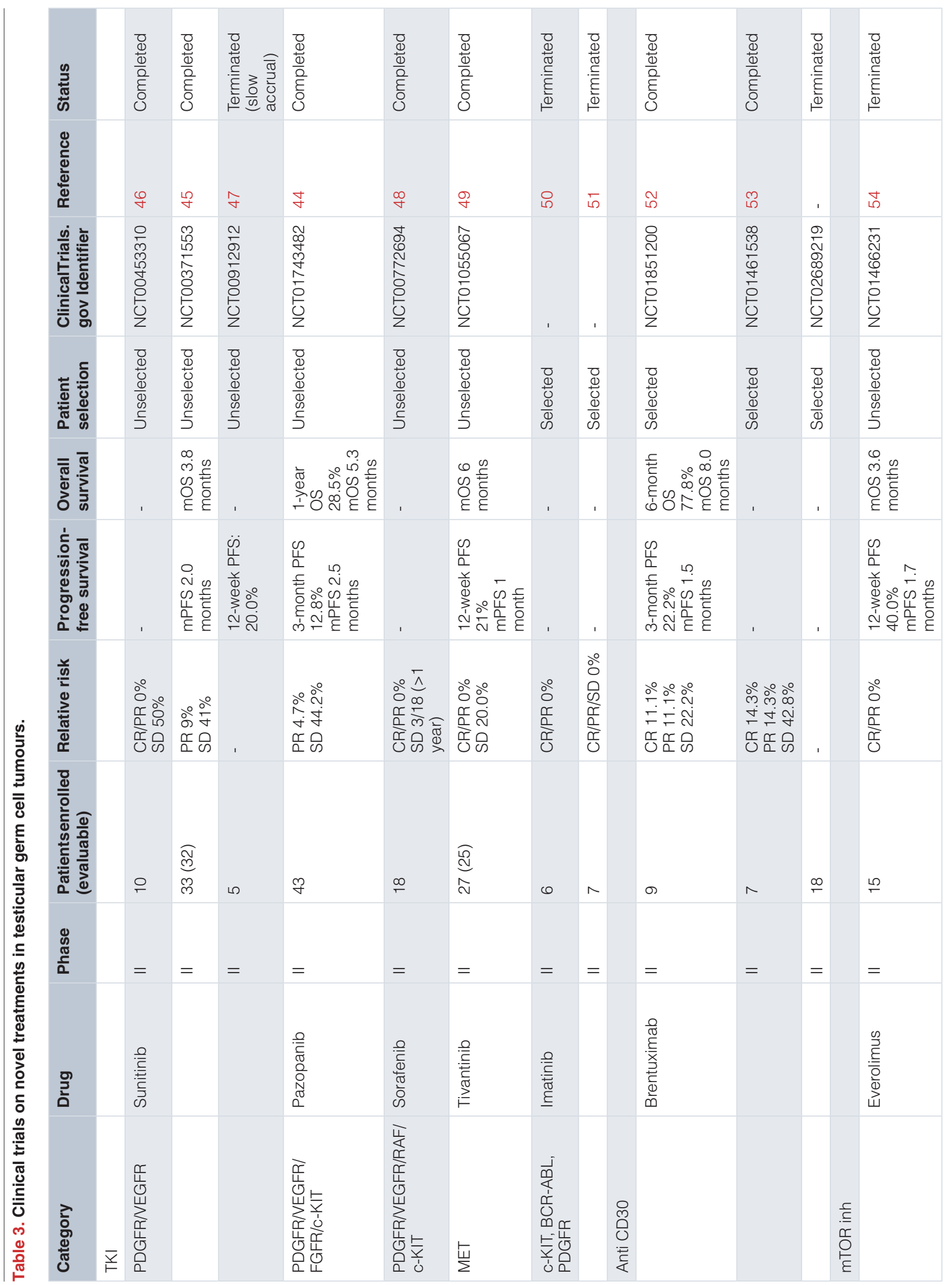




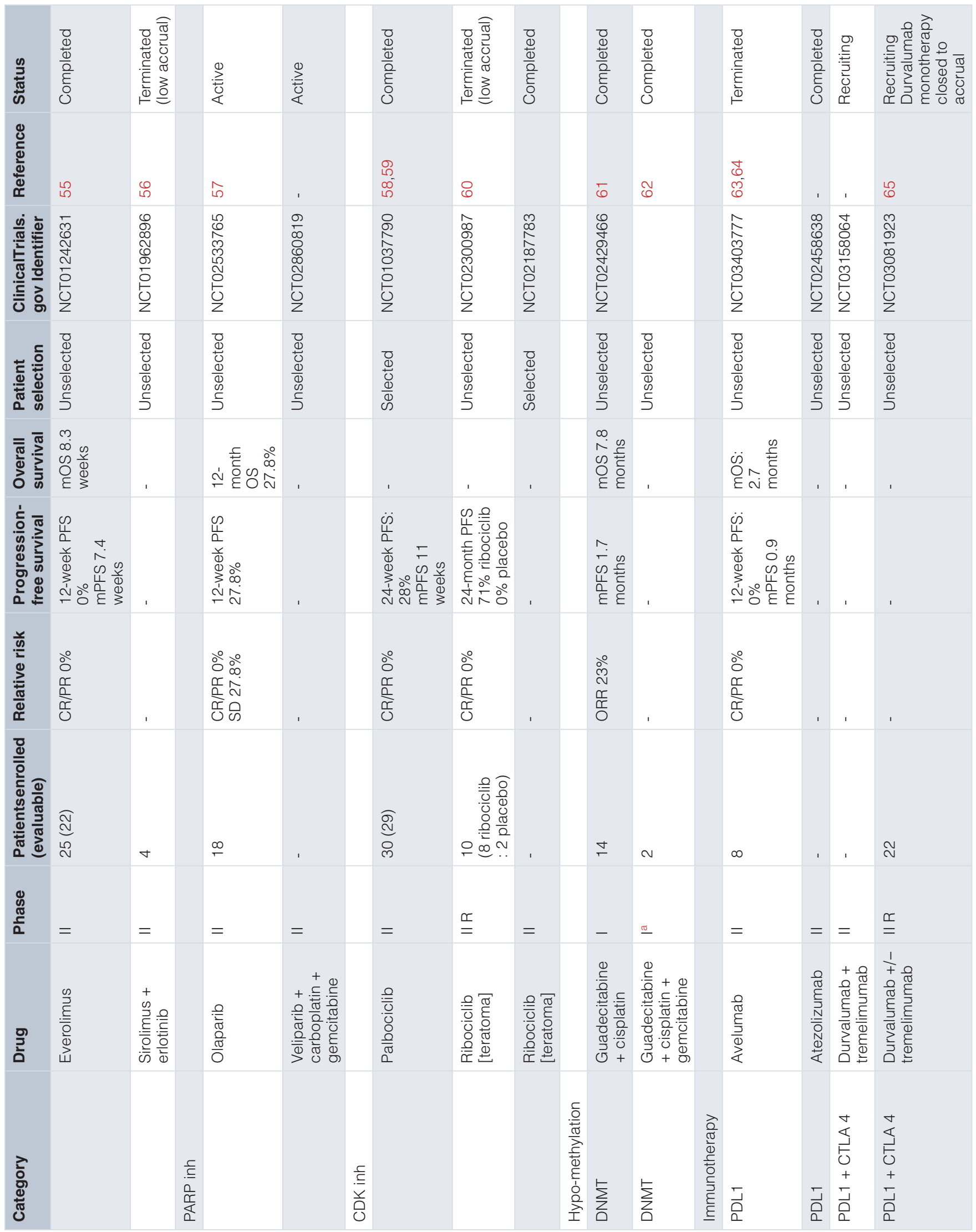




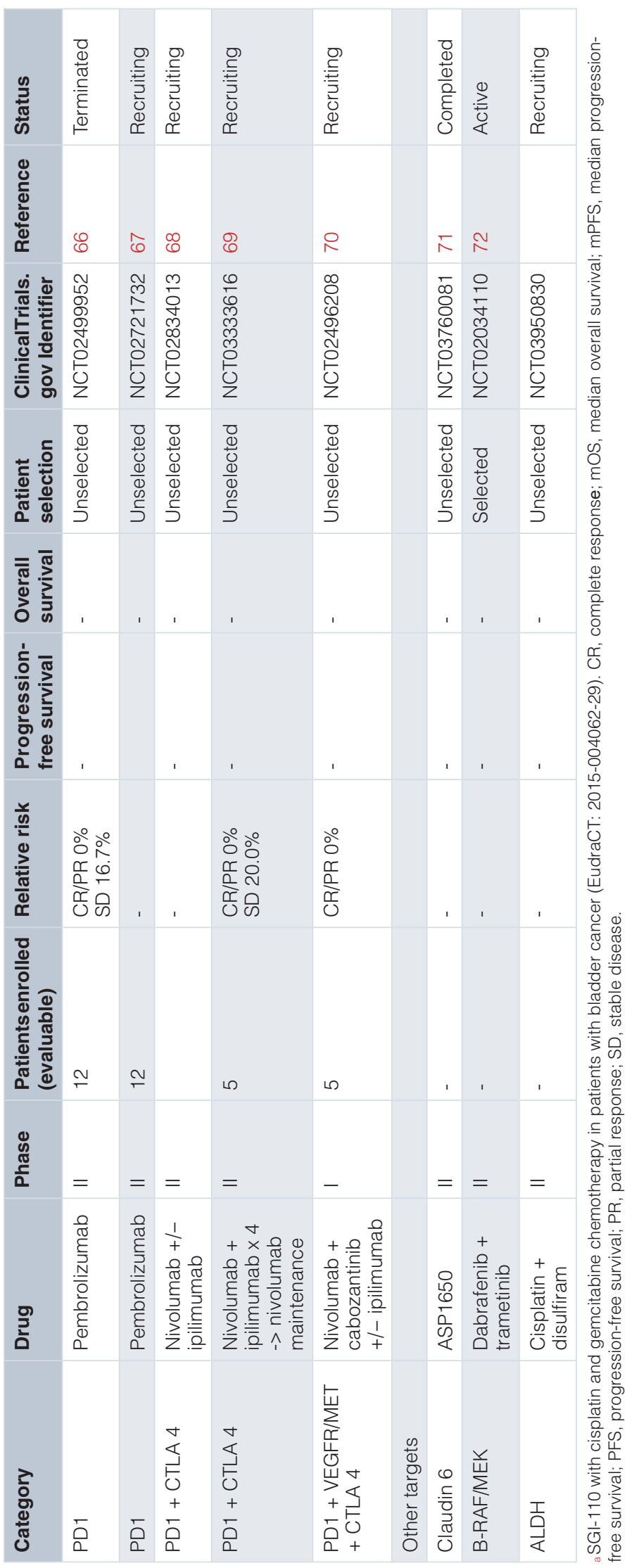


The role of KIT in genetic predisposition and the frequency of somatic mutations suggested this as an attractive target. Unfortunately, the reported responses with the tyrosine kinase inhibitors imatinib and tivantinib were disappointing ${ }^{49-51}$. This lack of activity may reflect the molecular features of TGCTs, as most identified KIT mutations are localised on exon 17 and associate with imatinib resistance ${ }^{41}$. Likewise, a phase II study of everolimus reported disappointing results ${ }^{55}$. A previous phase II study in the same setting was terminated because of futility; there were no responses in the first 15 patients who received treatment ${ }^{54}$. Similar results were reported in phase II studies addressing the cyclin-dependent kinases $C D K 4-6^{58-60}$. The hypothesis that cisplatin-sensitive tumours may also be sensitive to PARP inhibitors has led to testing of these inhibitors but with little evidence of activity to date ${ }^{57}$.

The lack of impact of targeted therapies on the disease has prompted exploration of alternative approaches.

Some activity has been seen with the antibody conjugate brentuximab vedotin targeting the CD30 antigen. In a small cohort of heavily pre-treated patients with CD30-expressing TGCTs, 3-month PFS and 6-month OS rates were $22.2 \%$ and $77.8 \%$ respectively ${ }^{52}$. In a different case series of seven patients who received brentuximab vedotin, two patients achieved an objective response $\mathrm{e}^{53}$.

PDL1 expression in a significant proportion of TGCTs has led to the exploration of checkpoint inhibitors despite the low tumour mutational burden of these cancers. However, studies of the PD1 inhibitor pembrolizumab and PDL1 inhibitors avelumab and durvalumab have failed to show clinical activity, and no responses were observed in TGCTs ${ }^{63-67}$.

Current studies are investigating PD1-directed agents alone or in combination (such as nivolumab + ipilimumab and durvalumab/tremelimumab ${ }^{68,69}$. Cabozantinib $+/-$ ipilimumab in a phase I study, however, showed no observed responses in the TGCT subgroup ${ }^{70}$.
Hypomethylating agents such as guadecitabine (SGI-110) have been suggested as potentially promising novel targets in view of the observed DNA hypermethylation exhibited by platinumrefractory TGCTs as opposed to platinum-sensitive tumours. In pre-clinical studies, TGCTs were extremely sensitive to lowdose decitabine, a DNA methyltransferase inhibitor, which restored sensitivity to cisplatin in cell lines ${ }^{73}$. A phase I study of guadecitabine and cisplatin in 14 patients with TGCTs showed an overall response rate of $23 \%{ }^{61}$; excellent responses were also reported in two patients with platinum-refractory disease treated in a phase 1 study of cisplatin, gemcitabine and guadecitabine $^{62}$.

It is still unknown to what extent the lack of activity observed with the majority of these agents is due to patient selection or to TGCT intrinsic biology. Certainly, further research on biomarkers is needed to identify novel treatments in refractory disease.

\section{Conclusions}

TGCTs are a heterogeneous group of diseases which in general have excellent cure rates that have improved over the last three decades. Treatment and cure of cisplatin-refractory disease are challenging, and the optimal treatment for these patients is not yet clear. Further research on cisplatin resistance is needed to expand the current therapeutic options and to achieve better outcomes for patients with refractory disease.

Promising novel biomarkers are being investigated and should their role be fully validated, the management of patients with TGCTs will certainly evolve.

Given the complexity of its management and multimodality treatment, referral to high-volume centres is crucial. As with any rare disease, international scientific collaboration such as the International Global Germ Cell Tumor Collaborative Group (G3) and the Malignant Germ Cell International Consortium (MaGIC) is the key to allow faster advances in research and clinical practice.
1. Bosl GJ, Motzer RJ: Testicular germ-cell cancer. N Engl J Med. 1997; 337(4): 242-53.

PubMed Abstract | Publisher Full Text

2. Horwich A, Shipley J, Huddart R: Testicular germ-cell cancer. Lancet. 2006; 367(9512): 754-65.

PubMed Abstract | Publisher Full Text

3. Bray F, Ferlay J, Soerjomataram I, et al.: Global cancer statistics 2018: GLOBOCAN estimates of incidence and mortality worldwide for $\mathbf{3 6}$ cancers in 185 countries. CA Cancer J Clin. 2018; 68(6): 394-424. PubMed Abstract | Publisher Full Text | Faculty Opinions Recommendation

4. Gurney JK, Florio AA, Znaor A, et al:: International Trends in the Incidence of Testicular Cancer: Lessons from 35 Years and 41 Countries. Eur Urol. 2019;
76(5): 615-23.

PubMed Abstract | Publisher Full Text | Faculty Opinions Recommendation

5. Moch H, Cubilla AL, Humphrey PA, et al:: The 2016 WHO Classification of Tumours of the Urinary System and Male Genital Organs-Part A: Renal, Penile, and Testicular Tumours. Eur Urol. 2016; 70(1): 93-105. PubMed Abstract | Publisher Full Text

6. Einhorn $\mathrm{LH}$, Donohue J: Cis-diamminedichloroplatinum, vinblastine, and bleomycin combination chemotherapy in disseminated testicular cancer. Ann Intern Med. 1977; 87(3): 293-8.

PubMed Abstract | Publisher Full Text

7. Feldman DR, Bosl GJ, Sheinfeld J, et al.: Medical treatment of advanced testicular cancer. JAMA. 2008; 299(6): 672-84.

PubMed Abstract | Publisher Full Text 
8. Porcu P, Bhatia S, Sharma M, et al.: Results of treatment after relapse from high-dose chemotherapy in germ cell tumors. J Clin Oncol. 2000; 18(6): 1181-6. PubMed Abstract | Publisher Full Text

9. International Germ Cell Consensus Classification: A prognostic factor-based staging system for metastatic germ cell cancers. International Germ Cell Cancer Collaborative Group. J Clin Oncol. 1997; 15(2): 594-603.

PubMed Abstract | Publisher Full Text

10. Gillessen S, Collette L, Daugaard G, et al.: 9030 - Redefining the IGCCCG classification in advanced non-seminoma. Ann Oncol. 2019; 30(Supplement 5): v357-v358.

Publisher Full Text

11. Beyer J, Collette L, Daugaard G, et al.: Prognostic factors in advanced seminoma: An analysis from the IGCCCG Update Consortium. J Clin Oncol. 2020; 38(6_suppl): 386

Publisher Full Text

12. Gilligan TD, Seidenfeld J, Basch EM, et al:: American Society of Clinical Oncology Clinical Practice Guideline on uses of serum tumor markers in adult males with germ cell tumors. J Clin Oncol. 2010; 28(20): 3388-404. PubMed Abstract | Publisher Full Text

13. Murray MJ, Huddart RA, Coleman N: The present and future of serum diagnostic tests for testicular germ cell tumours. Nat Rev Urol. 2016; 13(12): 715-25. PubMed Abstract | Publisher Full Text

14. Palmer RD, Murray MJ, Saini HK, et al:: Malignant germ cell tumors display common microRNA profiles resulting in global changes in expression of messenger RNA targets. Cancer Res. 2010; 70(7): 2911-23.

PubMed Abstract | Publisher Full Text | Free Full Text

15. Murray MJ, Halsall DJ, Hook CE, et al:: Identification of microRNAs From the miR-371 373 and miR-302 clusters as potential serum biomarkers of malignant germ cell tumors. Am J Clin Pathol. 2011; 135(1): 119-25. PubMed Abstract | Publisher Full Text

16. Gillis AJM, Rijlaarsdam MA, Eini R, et al.: Targeted serum miRNA (TSmiR) test for diagnosis and follow-up of (testicular) germ cell cancer patients: A proof of principle. Mol Oncol. 2013; 7(6): 1083-92. PubMed Abstract | Publisher Full Text | Free Full Text

17. Dieckmann KP, Radtke A, Geczi L, et al:: Serum Levels of MicroRNA-371a-3p (M371 Test) as a New Biomarker of Testicular Germ Cell Tumors: Results of a Prospective Multicentric Study. J Clin Oncol. 2019; 37(16): 1412-23. PubMed Abstract | Publisher Full Text | Free Full Text | Faculty Opinions Recommendation

18. Lafin JT, Singla N, Woldu SL, et al.: Serum MicroRNA-371a-3p Levels Predict Viable Germ Cell Tumor in Chemotherapy-naïve Patients Undergoing Retroperitoneal Lymph Node Dissection. Eur Urol. 2020; 77(2): 290-2. PubMed Abstract | Publisher Full Text | Free Full Text | Faculty Opinions Recommendation

19. - Leão R, van Agthoven T, Figueiredo A, et al.: Serum miRNA Predicts Viable Disease after Chemotherapy in Patients with Testicular Nonseminoma Germ Cell Tumor. J Urol. 2018; 200(1): 126-35.

PubMed Abstract | Publisher Full Text | Faculty Opinions Recommendation

20. Nappi L, Thi M, Lum A, et al.: Developing a Highly Specific Biomarker for Germ Cell Malignancies: Plasma miR371 Expression Across the Germ Cell Malignancy Spectrum. J Clin Oncol. 2019; 37(33): 3090-8. PubMed Abstract | Publisher Full Text | Free Full Text | Faculty Opinions Recommendation

21. Almstrup K, Lobo J, Mørup N, et al.: Application of miRNAs in the diagnosis and monitoring of testicular germ cell tumours. Nat Rev Urol. 2020; 17(4): 201-13.

PubMed Abstract | Publisher Full Text | Faculty Opinions Recommendation

22. Litchfield K, Thomsen H, Mitchell JS, et al.: Quantifying the heritability of testicular germ cell tumour using both population-based and genomic approaches. Sci Rep. 2015; 5: 13889. PubMed Abstract | Publisher Full Text | Free Full Text

23. Oosterhuis JW, Looijenga LHJ: Human germ cell tumours from a developmental perspective. Nat Rev Cancer. 2019; 19(9): 522-37. PubMed Abstract | Publisher Full Text | Faculty Opinions Recommendation

24. Litchfield K, Levy M, Orlando G, et al.: Identification of 19 new risk loci and potential regulatory mechanisms influencing susceptibility to testicular germ cell tumor. Nat Genet. 2017; 49(7): 1133-40.

PubMed Abstract | Publisher Full Text | Free Full Text

25. Wang Z, McGlynn KA, Rajpert-De Meyts E, et al:: Meta-analysis of five genomewide association studies identifies multiple new loci associated with testicular germ cell tumor. Nat Genet. 2017; 49(7): 1141-7. PubMed Abstract | Publisher Full Text | Free Full Tex

26. Litchfield K, Levy M, Huddart RA, et al.: The genomic landscape of testicular germ cell tumours: From susceptibility to treatment. Nat Rev Urol. 2016; 13(7): 409-19.

PubMed Abstract | Publisher Full Text

27. Atkin NB, Baker MC: Specific chromosome change, i(12p), in testicular tumours? Lancet. 1982; 2(8311): 1349.

PubMed Abstract | Publisher Full Text

28. Summersgill B, Osin P, Lu YJ, et al.: Chromosomal imbalances associated with carcinoma in situ and associated testicular germ cell tumours of adolescents and adults. Br J Cancer. 2001; 85(2): 213-20.

PubMed Abstract | Publisher Full Text | Free Full Text

29. Litchfield K, Summersgill B, Yost S, et al.: Whole-exome sequencing reveals the mutational spectrum of testicular germ cell tumours. Nat Commun. 2015; 6 : 5973.

PubMed Abstract | Publisher Full Text | Free Full Text

30. Shen $\mathrm{H}$, Shih J, Hollern DP, et al: Integrated Molecular Characterization of Testicular Germ Cell Tumors. Cell Rep. 2018; 23(11): 3392-406.

PubMed Abstract | Publisher Full Text | Free Full Text |

Faculty Opinions Recommendation

31. Motzer RJ, Geller NL, Tan CCY, et al.: Salvage chemotherapy for patients with germ cell tumors. The memorial sloan-kettering cancer center experience (1979-1989). Cancer 1991; 67(5): 1305-10.

PubMed Abstract | Publisher Full Text

32. Loehrer PJ Sr, Gonin R, Nichols CR, et al.: Vinblastine plus ifosfamide plus cisplatin as initial salvage therapy in recurrent germ cell tumor. $J$ Clin Oncol. 1998; 16(7): 2500-4

PubMed Abstract | Publisher Full Text

33. Kondagunta GV, Bacik J, Donadio A, et al:: Combination of paclitaxel, ifosfamide, and cisplatin is an effective second-line therapy for patients with relapsed testicular germ cell tumors. J Clin Oncol. 2005; 23(27): 6549-55. PubMed Abstract | Publisher Full Text

34. Pico JL, Rosti G, Kramar A, et al:: A randomised trial of high-dose chemotherapy in the salvage treatment of patients failing first-line platinum chemotherapy for advanced germ cell tumours. Ann Oncol. 2005; 16(7): 1152-9. PubMed Abstract | Publisher Full Text

35. Einhorn LH, Williams SD, Chamness A, et al:: High-dose chemotherapy and stemcell rescue for metastatic germ-cell tumors. N Engl J Med. 2007; 357(4): 340-8. PubMed Abstract | Publisher Full Text

36. Feldman DR, Sheinfeld J, Bajorin DF, et al.: TI-CE high-dose chemotherapy for patients with previously treated germ cell tumors: Results and prognostic factor analysis. J Clin Oncol. 2010; 28(10): 1706-13. PubMed Abstract | Publisher Full Text | Free Full Text Faculty Opinions Recommendation

37. Lorch A, Kleinhans A, Kramar A, et al.: Sequential versus single high-dose chemotherapy in patients with relapsed or refractory germ cell tumors: Longterm results of a prospective randomized trial. J Clin Oncol. 2012; 30(8): 800-5. PubMed Abstract | Publisher Full Text | Faculty Opinions Recommendation

38. Adra N, Abonour R, Althouse SK, et al.: High-Dose Chemotherapy and Autologous Peripheral-Blood Stem-Cell Transplantation for Relapsed Metastatic Germ Cell Tumors: The Indiana University Experience. J Clin Oncol. 2017; 35(10): 1096-102.

PubMed Abstract | Publisher Full Text | Free Full Text

39. De Vries G, Rosas-Plaza X, van Vugt MATM, et al:: Testicular cancer: Determinants of cisplatin sensitivity and novel therapeutic opportunities. Cancer Treat Rev. 2020; 88: 102054 PubMed Abstract | Publisher Full Text | Faculty Opinions Recommendation

40. Taylor-Weiner A, Zack T, O'Donnell E, et al.: Genomic evolution and chemoresistance in germ-cell tumours. Nature. 2016; 540(7631): 114-8. PubMed Abstract | Publisher Full Text | Free Full Text

41. Bagrodia A, Lee BH, Lee W, et al:: Genetic Determinants of Cisplatin Resistance in Patients With Advanced Germ Cell Tumors. J Clin Oncol. 2016; 34(33): 4000-7. PubMed Abstract | Publisher Full Text | Free Full Text

42. Loveday C, Litchfield K, Proszek PZ, et al.: Genomic landscape of platinum resistant and sensitive testicular cancers. Nat Commun. 2020; 11(1): 2189. PubMed Abstract | Publisher Full Text | Free Full Text

43. Galvez-Carvajal L, Sanchez-Muñoz A, Ribelles N, et al.: Targeted treatment approaches in refractory germ cell tumors. Crit Rev Oncol Hematol. 2019; 143 130-8.

PubMed Abstract | Publisher Full Text | Faculty Opinions Recommendation

44. Necchi A, Lo Vullo S, Giannatempo P, et al:: Pazopanib in advanced germ cell tumors after chemotherapy failure: Results of the open-label, single-arm, phase 2 Pazotest trial. Ann Oncol. 2017; 28(6): 1346-51.

PubMed Abstract | Publisher Full Text

45. Oechsle K, Honecker F, Cheng T, et al.: Preclinical and clinical activity of sunitinib in patients with cisplatin-refractory or multiply relapsed germ cell tumors: A Canadian Urologic Oncology Group/German Testicular Cancer Study Group cooperative study. Ann Oncol. 2011; 22(12): 2654-60. PubMed Abstract | Publisher Full Text

46. Feldman DR, Turkula S, Ginsberg MS, et al:: Phase II trial of sunitinib in patients with relapsed or refractory germ cell tumors. Invest New Drugs. 2010; 28(4): 523-8.

PubMed Abstract | Publisher Full Text

47. Subbiah V, Meric-Bernstam F, Mills GB, et al:: Next generation sequencing analysis of platinum refractory advanced germ cell tumor sensitive to Sunitinib (Sutent $囚$ ) a VEGFR2/PDGFRß/c-kit/ FLT3/RET/CSF1R inhibitor in a phase II trial. J Hematol Oncol. 2014; 7: 52. PubMed Abstract | Publisher Full Text | Free Full Text

48. Skoneczna IA, Natorska U, Tacikowska M, et al.: Sorafenib monotherapy in patients with inoperable/recurrent germ cell tumors (GCT) refractory to 
chemotherapy: Phase II study. J Clin Oncol. 2014; 32(4_suppl): 367. Publisher Full Text

49. Feldman DR, Einhorn LH, Quinn DI, et al:: A phase 2 multicenter study of tivantinib (ARQ 197) monotherapy in patients with relapsed or refractory germ cell tumors. Invest New Drugs. 2013; 31(4): 1016-22. PubMed Abstract | Publisher Full Text

50. Einhorn LH, Brames MJ, Heinrich MC, et al.: Phase II study of imatinib mesylate in chemotherapy refractory germ cell tumors expressing KIT. Am J Clin Oncol. 2006; 29(1): 12-3.

PubMed Abstract | Publisher Full Text

51. Piulats JM, Garcia del Muro X, Huddart R, et al.: Phase II multicenter study of imatinib in patients with chemorefractory germ cell tumors that express c-kit. Cancer Res. 2007; 67(9 Supplement): 2648 LP-2648. Reference Source

52. Necchi A, Anichini A, Raggi D, et al.: Brentuximab Vedotin in CD30-Expressing Germ Cell Tumors After Chemotherapy Failure. Clin Genitourin Cancer. 2016; 14(4): 261-264.e4

PubMed Abstract | Publisher Full Tex

53. Albany C, Einhorn L, Garbo L, et al.: Treatment of CD30-Expressing Germ Cell Tumors and Sex Cord Stromal Tumors with Brentuximab Vedotin: Identification and Report of Seven Cases. Oncologist. 2018; 23(3): 316-23. PubMed Abstract | Publisher Full Text | Free Full Text | Faculty Opinions Recommendation

54. Mego M, Svetlovska D, Miskovska V, et al:: Phase II study of everolimus in refractory testicular germ cell tumors. Urol Oncol. 2016; 34(3): 122.e17-22. PubMed Abstract | Publisher Full Text

55. Fenner M, Oing C, Dieing A, et al.: Everolimus in patients with multiply relapsed or cisplatin refractory germ cell tumors: Results of a phase II, single-arm, open-label multicenter trial (RADIT) of the German Testicular Cancer Study Group. J Cancer Res Clin Oncol. 2019; 145(3): 717-23. PubMed Abstract | Publisher Full Text

56. Laetsch TW, Kumar K, Rakheja D, et al.: A phase II study of sirolimus and erlotinib in recurrent/refractory germ cell tumors. J Clin Oncol. 2014; 32(15 suppl): TPS2638. Publisher Full Text

57. de Giorgi U, Schepisi G, Gurioli G, et al.: Olaparib as salvage treatment for advanced germ cell tumors after chemotherapy failure: Results of the open-label, single-arm, IGG-02 phase II trial. J Clin Oncol. 2020; 38(15): 5058. Publisher Full Text

58. Vaughn DJ, Hwang WT, Lal P, et al:: Phase 2 trial of the cyclin-dependent kinase $4 / 6$ inhibitor palbociclib in patients with retinoblastoma protein-expressing germ cell tumors. Cancer. 2015; 121(9): 1463-8. PubMed Abstract | Publisher Full Text

59. Narayan V, Hwang WT, Lal P, et al:: Cyclin-Dependent Kinase 4/6 Inhibition for the Treatment of Unresectable Mature Teratoma: Long-Term Follow-Up of a Phase II Study. Clin Genitourin Cancer. 2016; 14(6): 504-10. PubMed Abstract | Publisher Full Text

60. Castellano DE, Quinn DI, Feldman DR, et al:: A phase II study of ribociclib in men with unresectable, incurable teratoma with recent progression. J Clin Oncol. 2019; 37(7): 517

Publisher Full Text

61. Albany C, Fazal Z, Singh R, et al.: A phase 1 study of combined guadecitabine and cisplatin in platinum refractory germ cell cancer. Cancer
Med. 2021; 10(1): 156-63.

PubMed Abstract | Publisher Full Text | Free Full Text |

Faculty Opinions Recommendation

62. Crabb SJ, Huddart RA, Brown E, et al.: Response to guadecitabine (SGI-110) combined with cisplatin and gemcitabine (GCG) in platinum refractory germ cell tumors (GCTs). J Clin Oncol. 2020; 38(15_suppl): e17057. Publisher Full Text

63. Mego M, Svetlovska D, Chovanec M, et al.: Phase II study of avelumab in multiple relapsed/refractory germ cell cancer. Invest New Drugs. 2019; 37(4): 748-54. PubMed Abstract | Publisher Full Text

64. Mego M, Svetlovska D, Chovanec M, et al.: Phase II study of avelumab in multiple relapsed/refractory testicular germ cell cancer. J Clin Oncol. 2019; 37(15 suppl): e16045

Publisher Full Text | Faculty Opinions Recommendation

65. Necchi A, Giannatempo P, Raggi D, et al.: An Open-label Randomized Phase 2 study of Durvalumab Alone or in Combination with Tremelimumab in Patients with Advanced Germ Cell Tumors (APACHE): Results from the First Planned Interim Analysis. Eur Urol. 2019; 75(1): 201-3. PubMed Abstract | Publisher Full Text

66. Adra N, Einhorn LH, Althouse SK, et al.: Phase II trial of pembrolizumab in patients with platinum refractory germ-cell tumors: A Hoosier Cancer Research Network Study GU14-206. Ann Oncol. 2018; 29(1): 209-14. PubMed Abstract | Publisher Full Text | Faculty Opinions Recommendation

67. Naing A, Meric-Bernstam F, Stephen B, et al:: Phase 2 study of pembrolizumab in patients with advanced rare cancers. J Immunother Cancer. 2020; 8(1): e000347. PubMed Abstract | Publisher Full Text | Free Full Text

68. Patel SP, Othus M, Chae YK, et al.: SWOG 1609 (DART): A phase II basket tria of dual anti-CTLA-4 and anti-PD-1 blockade in rare tumors. J Clin Oncol. 2019; 37(15_suppl): TPS2658.

Publisher Full Text

69. McGregor BA, Campbell MT, Xie W, et al.: Phase II study of nivolumab and ipilimumab for advanced rare genitourinary cancers. J Clin Oncol. 2020; 38(15_suppl): 5018.

Publisher Full Text

70. Nadal RM, Mortazavi A, Stein M, et al:: Results of phase I plus expansion cohorts of cabozantinib (Cabo) plus nivolumab (Nivo) and CaboNivo plus ipilimumab (Ipi) in patients (pts) with with metastatic urothelial carcinoma (mUC) and other genitourinary (GU) malignancies. J Clin Oncol. 2018; 36(6_suppl): 515 . Publisher Full Text

71. Adra N, Vaughn DJ, Einhorn L, et al.: A phase II study assessing the safety and efficacy of ASP1650 in male patients with incurable platinum refractory germ cell tumors. J Clin Oncol. 2020; 38(6 suppl): TPS424. Publisher Full Text

72. Subbiah V, Bang YJ, Lassen UN, et al.: ROAR: A phase 2, open-label study in patients (pts) with BRAF V600E-mutated rare cancers to investigate the efficacy and safety of dabrafenib (D) and trametinib (T) combination therapy. $J$ Clin Oncol. 2016; 34(15 suppl): TPS2604. Publisher Full Text

73. Beyrouthy MJ, Garner KM, Hever MP, et al:: High DNA methyltransferase 3B expression mediates 5-aza-deoxycytidine hypersensitivity in testicular germ cell tumors. Cancer Res. 2009; 69(24): 9360-6. PubMed Abstract | Publisher Full Text | Free Full Text 